Prof. dr. sc. Duško Lozina

Pravni fakultet Sveučilišta u Splitu

Dr. sc. Damir Juras

Ministarstvo unutarnjih poslova Republike Hrvatske ${ }^{1}$

\title{
NEKE KARAKTERISTIKE LOKALNE SAMOUPRAVE NA PROSTORU IMOTSKE KRAJINE I OTOKA BRAČA
}

$U D K: 352$

DOI: $10.31141 /$ zrpfs.2019.56.134.817

Izvorni znanstveni rad

Primljeno: 15. VII. 2019.

U ovom radu autori prikazuju stanje lokalne samouprave na primjeru dviju skupina jedinica lokalne samouprave, različitih po svom geografskom, ekološkom, prostornom i drugim obilježjima. Riječ je o prostoru Imotske krajine koja je, od nekoć jedinstvenog teritorijalnog prostora, diferencirana na 8 općina i grad Imotski, te o otoku Braču koji je podijeljen na 7 općina i grad Supetar. Upravo ta različitost u okviru Splitsko-dalmatinske županije temeljni je spiritus movens ovoga rada, bez pretenzija da ova analiza dade apodiktične i kategorične sudove, primjerice o tome je li nova teritorijalna organizacija dovela do poboljšanja i jačanja svekolikih kapaciteta lokalne samouprave.

Ključne riječi: Imotska krajina, lokalna samouprava, otok Brač, Splitsko-dalmatinska županija, veličina lokalnih jedinica

\section{UVOD}

Lokalna je razina temeljna razina samouprave, ona na kojoj se ostvaruju glavne svrhe radi kojih teritorijalna samouprava postoji. U tom smislu u suvremenoj upravnoj teoriji, ne samo hrvatskoj nego i šire, uzima se činjenica da lokalna samouprava u suvremenom svijetu ima sve veću važnost u višerazinskom konceptu vlasti, koji počinje od države, preko lokalne i područne (regionalne) samouprave, sve do submunicipalnih oblika organizacije prostora.

Kao što je poznato, radikalan zaokret u organizaciji lokalne samouprave u Republici Hrvatskoj dogodio se 1992. godine donošenjem Zakona o lokalnoj samoupravi i upravi ${ }^{2}$ kojim je iz temelja zamijenjen komunalni sustav koji je bio obilježje dotadašnjeg teritorijalnog uređenja države. Kao temeljne jedinice lokalne

1 Prof. dr. sc. Duško Lozina, Pravni fakultet Sveučilišta u Splitu, e-mail: duskolozina7@gmail.com

Dr. sc. Damir Juras, Ministarstvo unutarnjih poslova Republike Hrvatske, e-mail: djuras@mup.hr, Damir.Juras@xnet.hr

2 Zakon o lokalnoj samoupravi i upravi, NN 90/92, 94/93, 117/93, 5/97, 17/99, 128/99, 51/00, 105/00. 
samouprave utvrđene su općine i gradovi, dok su županije utvrđene kao jedinice lokalne uprave i samouprave. Navedeni je Zakon višekratno noveliran jer su nastale tektonske promjene u okruženju u kojem živimo i one su svoj logični odraz pronašle i u modalitetima organizacije hrvatskog teritorija.

Općenito, smatra se da je postojeća teritorijalna struktura Hrvatske previše složena, nedovoljno stabilna i učinkovita te neracionalna s gledišta potrebe za ostvarenjem razvojnih svrha države, te da je Hrvatska obilježena centralističkim načinom upravljanja zemljom. ${ }^{3}$

Broj jedinica lokalne samouprave se u razdoblju od 30. prosinca 1992. godine ${ }^{4}$ značajno povećao od početnih 486 i u ovom trenutku u Hrvatskoj je ustrojeno 555 jedinica lokalne samouprave, od čega 428 općina i 127 gradova. ${ }^{5}$ Navedeni pokazatelji rječito svjedoče o tendenciji povećanja broja jedinica lokalne samouprave u Hrvatskoj, koja u europskim razmjerima ima razvojnu putanju, inkompatibilnu većini europskih zemalja, isključujući Francusku koja po broju teritorijalnih jedinica prednjači među europskim državama, a tu bi se mogla pridružiti i susjedna Slovenija. Sve druge razvijene europske države pokazuju drugačiju tendenciju, a to je znatno smanjivanje broja teritorijalnih jedinica jer one dovode do navodno veće funkcionalnosti u obavljanju lokalnih, ali i državnih poslova. U okviru ovog diskursa posebno je zanimljivo inzistiranje prof. Koprića na činjenici da bi broj jedinica lokalne samouprave u Hrvatskoj trebalo smanjiti na nekih 150 općina, a gradovi bi trebali, po njegovu mišljenju, postati osnovni generatori razvoja lokalne samouprave. ${ }^{6}$ Političke elite su suspektne prema takvom prijedlogu i nije izgledno da će tako skoro doći do nove arhitekture sustava lokalne samouprave.

Bez namjere ulaženja u vrijednosne sudove koja je optimalna veličina jedinica lokalne samouprave potrebno je, nastojeći se držati načela "sine ira et studio", ukazati na neka razmišljanja o tom području. Akademik Pusić smatra da su četiri glavna načela koja bi se trebala poštovati u procesu diobe državnog teritorija, a to su: 1. potpunost, 2. jednakost - po mogućnosti što sličniji po veličini, 3 .

\footnotetext{
3 Koprić, Ivan, "Karakteristike sustava lokalne samouprave u Hrvatskoj", Hrvatska javna uprava, 2/2010, str. 372 .

${ }^{4}$ Zakon o područjima županija, gradova i općina u Republici Hrvatskoj, NN 90/1992, kojim je izvršena nova teritorijalna podjela Republike Hrvatske, stupio je na snagu danom objave u službenom glasilu Republike Hrvatske dana 30. XII. 1992. godine.

https://uprava.gov.hr/o-ministarstvu/ustrojstvo/uprava-za-politicki-sustav-i-organizaciju-uprave/ lokalna-i-podrucna-regionalna-samouprava/popis-zupanija-gradova-i-opcina/846 (2. IX. 2019.).

6 Koprić, Ivan, Dvadeset godina lokalne i područne (regionalne) samouprave u Hrvatskoj: razvoj, stanje i perspektive, str. 25-27,

https://s3.amazonaws.com/academia.edu.documents/36414896/Kopric-Dvadeset_godina_LRSMP_predavanja_2012_1_.pdf?response-content-disposition=inline\%3B\%20filename\%3DDvadeset_ godina_lokalne_i_podrucne_regio.pdf\&X-Amz-Algorithm=AWS4-HMAC-SHA256\&X-Amz-Crede ntial=AKIAIWOWYYGZ2Y53UL3A\%2F20190910\%2Fus-east-1\%2Fs3\%2Faws4_request\&X-Amz-

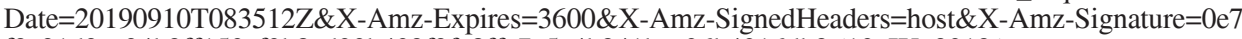
f2e31d3cc34b9ff150ef0b8cd00b409f3fe8ffe7e5a4b941bea06b4016db9 (10. IX. 2019.).
} 
gospodarsko-financijska samodovoljnost i 4. dostupnost. ${ }^{7}$ Prof. Pavić polazi od pretpostavke da su velike lokalne jedinice sposobne obnašati sve više modernih diferenciranih, specijaliziranih upravnih poslova, koji su posljedica značajnih društvenih promjena. $\mathrm{S}$ druge strane prednosti malih jedinica treba potražiti $\mathrm{u}$ samoj ideji lokalne samouprave. Unutar tog diskursa potrebna je blizina za sve ono što je ljudima za njihov organiziran život bitno i nužno unutar prostora koji nastanjuju. ${ }^{8}$ Male lokalne jedinice doprinose očuvanju harmonije lokalne zajednice i duha u kojem svaki građanin osjeća da ima mogućnost biti politički učinkovit, ${ }^{9}$ dok samo povećanje teritorija lokalne jedinice ne djeluje na istodobno povećanje njezina financijskog kapaciteta, niti utječe na glavne pokazatelje opsega upravne djelatnosti, opterećenosti i kvalificiranosti upravnih kadrova i uređenje raspodjele sredstava u takvoj upravi. ${ }^{10}$

Usprkos negativnim depopulacijskim pokazateljima i velikim disparitetima u veličini jedinica lokalne samouprave, činjenica je da su mnoge čak i najmanje lokalne jedinice u Republici Hrvatskoj postigle značajan iskorak, posebice na planu komunalne infrastrukture, komunalnog gospodarstva, prostornog planiranja, zaštite okoliša, razvoja autohtonih oblika turističke ponude, afirmacije lokalnih kulturnih sadržaja, održivog razvoja itd. Prof. Klarić u tom kontekstu napominje da su dva osnovna pitanja kojima se jedinice lokalne samouprave u Hrvatskoj danas bave: prostorno uređenje i komunalna djelatnost. ${ }^{11}$

Ovaj tekst, kao svojevrsni case study, na primjeru dviju grupa jedinica lokalne samouprave s različitim obilježjima (područje Imotske krajine i otoka Brača), želi pokazati kakve su performanse novog teritorijalnog uređenja u praksi i koje izazove i rješenja postojeće stanje pruža odnosno kakvi su ukupni kapaciteti (ljudski i financijski) lokalnih jedinica i kako se oni koriste.

7 Pusić, Eugen, Upravni sistemi, knjiga 1, Zagreb: Grafički zavod Hrvatske, Pravni fakultet u Zagrebu, Centar za stručno usavršavanje i suradnju s udruženim radom, 1985. Po akademiku Pusiću, mreža lokalnih jedinica treba u idealnom slučaju zadovoljiti sljedeće kriterije: obuhvatiti čitav državni teritorij bez ostatka; približiti se što većoj jednakosti po veličini i položaju između jedinica iste vrste i razine, postići što veću ekonomsko-financijsku samodovoljnost svih jedinica; omogućiti što lakši pristup stanovništva lokalnim organima i službama. Više o tome u navedenom djelu, str. 328-330. U kontekstu ovog problema upućuje se i na razmišljanja prof. Cvitana, koji kao faktore veličine pobraja zemljopisni, vremenski, gospodarski, sociološki, upravni faktor, te urbanizaciju. O tome vidi Onesin, Cvitan: Lokalna samouprava, Split: Veleučilište u Splitu, 2003., str. 14-16.

8 Pavić, Željko, "Veličina lokalnih jedinica - europske tendencije i hrvatske nedoumice", Hrvatska javna uprava, 1/2010, str. 82.

9 Humes, Samuel; Martin, Eileen, The Structure of Local Government, A Comparative Survey of 81 Countries, The Hague: International Union of Local Authorities, 1969., str. 67.

10 Pusić, Eugen, Teritorijalna konfiguracija lokalnog samoupravljanja u okviru ustavne koncepcije općine, Zagreb: Institut za društvena istraživanja Sveučilišta u Zagrebu, 1968., str. 262.

11 Opširnije o tome: Klarić, Mirko, "Moguće perspektive razvoja lokalne i regionalne samouprave u Republici Hrvatskoj", Zbornik radova Teritorijalni ustroj i regionalizacija Republike Hrvatske u kontekstu europskih integracija, Split: Pravni fakultet Sveučilišta u Splitu, 2010., str. 95-106. 


\section{OPĆA OBILJEŽJA IMOTSKE KRAJINE I OTOK BRAČA}

Imotska je krajina zemljopisno područje u Dalmatinskoj zagori, istočno od Sinjske i Omiške krajine, zapadno od Vrgoračke krajine. Velikim se dijelom prostire po Imotskom polju. Zauzima 708,34 km četvorna, a naseljava je 32.223 stanovnika. ${ }^{12}$

Imotska krajina dobila je naziv prema imenu grada Imotskoga, a ovaj od tvrđave oko koje se razvio. Imenovanje "krajina", po vodećim utvrdama ili gradskim naseljima na rubovima većih polja u kršu, također je bilo razložno jer su ona uz vojničke i upravne imala i druge središnje funkcije za okolna agrarno-stočarska područja. ${ }^{13}$ Tvrđava i grad nazvani su po starohrvatskoj župi Imota. Kroz dugu povijest Imota je mijenjala nazive i ustrojstva: u doba hrvatskog kraljevstva zvala se župa, za ugarsko-hrvatskog kraljevstva županija, a katkad i kneževina, za Turaka kadiluk, za Mlečana okrug, za Francuza kanton, u doba Austrije kotar. ${ }^{14}$ Poznato je da je dalmatinsko zaobalje dijelom 18. i 19. stoljeća zaista bilo krajiško područje

12 Podaci o aktualnom (sadašnjem - svibanj 2019.) broju stanovnika svih jedinica lokalne samouprave na području Imotske krajine i otoka Brača dobiveni su putem e-maila od Policijske uprave splitskodalmatinske dana 27. V. 2019. i koriste se kao relevantni u ovom radu. Navedeni podaci temelje se na evidenciji prebivališta u Informacijskom sustavu Ministarstva unutarnjih poslova Republike Hrvatske i trebali bi biti točni (precizni) jer se evidencija prebivališta svakodnevno ažurira po prijavama građana, ali i po službenoj dužnosti, s obzirom na to da Ministarstvo, temeljem čl. 12. Zakona o prebivalištu, NN 144/12, 158/13, odjavljuje (briše) odnosno moralo bi odjavljivati s adrese prebivališta sve osobe za koje utvrdi da stvarno ne žive na prijavljenoj adresi. Postoji razlika u navedenim službenim podacima Ministarstva i broju stanovnika navedenih jedinica lokalne samouprave sadržanih u Popisu stanovništva iz 2011.,

https://data.gov.hr/dataset/popis-stanovni-tva-2011-po-gradovima-op-inama/resource/9644ed4ea734-406d-b088-5c44ce9d077f (6. IX. 2019.) i u Popisu stanovništva iz 2001.,

https://www.dzs.hr/Hrv/censuses/Census2001/Popis/H01_01_02/h01_01_02_zup17.html（6. IX. 2019.), no ne može se kategorički tvrditi niti da se u jednoj ili objema evidencijama radi o netočnim podacima, ali se može i mora ukazati na posebnu metodologiju primijenjenu kod popisa stanovništva, koja je mijenjana za popis iz 2011. (Popis stanovništva, kućanstava i stanova 2011. godine, Metodološka objašnjenja, Usporedivost popisnih podataka, https://www.dzs.hr/Hrv/censuses/census2011/results/ censusmetod.htm) i na činjenicu da se kod popisa stanovništva može dogoditi da određene osobe, iz različitih razloga (odsutnost sa adrese zbog putovanja, studiranja, liječenja, površnost popisivača i dr.) ne budu popisane, kao i na činjenicu da na moguću nepreciznost podataka utječe i tzv. administrativno ili fiktivno doseljavanje (Nakićen, Jelena; Čuka, Ante, "Demografski razvoj otoka Brača i sklonost otočana iseljavanju", Migracijske i etničke teme, broj 3/2016, str. 321.), motivirano pogodnostima koje se ostvaruju temeljem prijavljenog prebivališta (primjerice, prava na povlašteni javni pomorski prijevoz i prava na povlašteni javni otočni cestovni prijevoz / čl. 30.-31. Zakona o otocima, NN 116/18). Jedan od praktičnih problema fiktivnih prebivališta vezuje se i uz provedbu referenduma u jedinicama lokalne samouprave: "Pisac ovog članka bio je kontaktiran od strane građana i dijela lokalnih vijećnika jedne otočke općine u Srednjoj Dalmaciji, koji su željeli raspisati referendum jer su bili nezadovoljni radom načelnika. Kao dodatni problem imali su okolnost da je prebivalište imao značajan broj Splićana porijeklom iz njihove općine, koji su ostvarivali čitav niz pogodnosti na otoku kao što su jeftinije trajektne karte, manji porez, naknada troškova prijevoza i sl.", Klarić, Mirko, "Zakonske novine vezane iz izvršne institucije u lokalnoj samoupravi", u: Koprić, Ivan; Đulabić, Vedran (ur.), Dvadeset godina lokalne samouprave u Hrvatskoj, Zagreb: Institut za javnu upravu, 2013., str. 135. U svakom slučaju, prikazani podaci u ovom radu ukazuju na potrebu da se propisi o prebivalištu i praksa u primjeni propisa podigne na najvišu razinu, kao i da se unaprijedi sustav popisa stanovništva.

13 Maras, Mate; Jukić, Branimir: "Zabiokovlje - značajnija prirodno-geografska obilježja", Zbornik radova: Zavičajna baština - HNOS i Kurikulum, Split: Književni krug, 2007., str. 11-26.

${ }_{14}$ Grbavac, Jozo: Povijest, vjera i kulturna baština u Imoti, Zagreb: Školska knjiga, 2017., str. 12. 
između Mletačke Republike i Osmanskog Carstva (koje je dugo vremena gospodarilo ovim i susjednim predjelima). Naziv Zabiokovlje više se koristi u novije vrijeme, a posebno od početka izgradnje autoceste Zagreb-Split-Dubrovnik.

Nekadašnja Imotska krajina imala je relativno razvijenu industriju. Po proizvodnji grožđa Imotska krajina bila je na prvom mjestu u Dalmaciji, a po proizvodnji duhana bila je prva općina u čitavoj Hrvatskoj. ${ }^{15}$ Proces litoralizacije negativno je utjecao na razvoj ovog kraja, potencirajući opće procese urbanizacije: deruralizaciju, deagrarizaciju, industrijalizaciju i tercijarizaciju hrvatskog društvenog i gospodarskog sustava. Osamostaljivanjem hrvatske države stvoreni su preduvjeti da se zaustavi proces raseljavanja i da započne dugo željeni reverzibilni proces povratak. U tom smislu, program revitalizacije napuštenih sela u Zabiokovlju, što ga je inicirala Splitsko-dalmatinska županija, javlja se u vrijeme kada je i hrvatska urbana populacija počela sve više otkrivati ruralni način života, nakon propasti klasičnog svijeta industrijske moderne. Revitalizacija je prvenstveno povezana s razvojem turizma i obiteljskih poljoprivrednih gospodarstava (OPG), čemu pogoduje da Zabiokovlje obiluje: razmjerno očuvanom i arhitektonski skladnom ruralnom cjelinom, izolacijom u prostoru na 300 metara nadmorske visine koja pruža osjećaj mira i tišine, planinskim masivom Biokova (Park prirode Biokovo) i mrežom pješačkih staza i potencijalno tematiziranih pješačkih i biciklističkih turističkih itinerera, sakralnom baštinom (crkve, župni dvori, "Zelena katedrala"), prirodnim znamenitostima (Crveno i Modro jezero, Prološko blato, ihtiološki rezervat gornjeg toka rijeke Vrljike), terasama podijeljenima suhozidima, tradicijom vinogradarstva, voćarstva i povrtlarstva, zavičajnim udrugama i kulturno-umjetničkim društvima, kulturnim manifestacijama. ${ }^{16}$

Ono što je posebno važno vidi se u činjenici da je državna vlast prepoznala otežane uvjete života i gospodarenja u određenim područjima Republike Hrvatske, pa je Zakonom o regionalnom razvoju Republike Hrvatske ${ }^{17}$ (čl. 38.a) odredila da se u svrhu prevladavanja razvojnih ograničenja odnosno posebnosti s kojima se suočavaju otoci i brdsko-planinska područja proglašavaju područjima s razvojnim posebnostima. Zakonom o brdsko-planinskim područjima ${ }^{18}$ (čl. 7. st. 1.) određeno je da se pod brdsko-planinskim područjima razumijevaju područja čija nadmorska visina, nagib, vertikalna raščlanjenost terena te njima uvjetovane pedološke,

15 Ujević, Ante, Imotska krajina, Imotski: Matica Hrvatska, 1991., str. 32.

16 Ora, Branko, "Ruralni turizam - prigoda za revitalizaciju napuštenih sela u Zabiokovlju", Zbornik radova Zavičajna baština - komparativna prednost i temeljnica održivog razvoja Zabiokovlja, Split: Književni krug, 2009., str. 272-291.

O ljepotama (privlačnosti) Imotskog i Brača trajni spomen, u pjesmi Odlazak, ostavio je i veliki hrvatski pjesnik Tin Ujević, čiji otac je bio iz Krivodola u Imotskoj krajini, a majka mu je bila Bračanka iz mjesta Milna:

"U slutnji, u čežnji daljine, daljine;

U srcu, u dahu planine, planine.

Malena mjesta srca moga,

Spomenak Brača, Imotskoga. (...)

17 Zakon o regionalnom razvoju Republike Hrvatske, NN 147/14, 123/2017, 118/18.

18 Zakon o brdsko-planinskim područjima, NN 118/18. 
klimatske i druge prirodne osobitosti predstavljaju otežane uvjete za život i rad stanovnika. Stavkom 3. istoga članka Zakona određeno je da se za utvrđivanje obuhvata brdsko-planinskoga područja primjenjuje multikriterijalna metoda odabira u kojoj se boduju geomorfološki, klimatski, demografski i infrastrukturni kriteriji. Člankom 15. istoga Zakona određeno je da su nositelji i sudionici razvoja brdskoplaninskih područja dužni u svojim planovima i programima posebno predviđati: demografske mjere, gospodarske mjere, fiskalne mjere, socijalne mjere, mjere jačanja administrativnih kapaciteta za učinkovit i održiv razvoj brdsko-planinskog područja, mjere za provedbu programa integriranih teritorijalnih ulaganja. Odlukom o obuhvatu i razvrstavanju jedinica lokalne samouprave koje stječu status brdskoplaninskog područja ${ }^{19}$ u I. skupinu jedinica lokalne samouprave sa statusom potpomognutog područja uvršteno je 7 općina Imotske krajine: Lokvičići, Zagvozd, Runovići, Podbablje, Lovreć, Cista Provo i Proložac.

Potpora ruralnim područjima dolazi i iz nekoliko fondova Europske unije: Europskog fonda za regionalni razvoj (EFRR), Europskog socijalnog fonda (ESF) i Europskog fonda za pomorstvo i ribarstvo (EFPR), koji u sinergiji dovode do postizanja vizije Europa 2020. Glavna misija politike ruralnog razvoja Europske unije u razdoblju 2014. - 2020. može se definirati kroz tri dugoročna strateška cilja koja trebaju pridonijeti konkurentnosti poljoprivrede, održivom upravljanju prirodnim resursima i klimatskim mjerama te prostorno uravnoteženom razvoju ruralnih područja.

I županijska razvojna strategija Splitsko-dalmatinske županije za razdoblje do 2020. godine ${ }^{20}$ nastoji stvoriti predispozicije za optimalan razvoj općina, gradova i otočnog areala. Udruživanjem Imotskog i osam općina Imotske krajine u Turističku zajednicu Imota Splitsko-dalmatinska županija postala je perjanica u udruživanju turističkih zajednica, a izradom Turističke strategije Imotske krajine do 2025. godine postala je primjer ostalima kako osmišljavati ravnopravan turistički razvoj uvažavajući specifičnosti lokalne zajednice s ciljem postizanja što većeg zadovoljstva i gostiju i domicilnog stanovništva. ${ }^{21}$

Brač je najveći srednjodalmatinski otok. Dug je oko 40 kilometara, a širok prosječno 12 kilometara, ukupne površine 395 km četvornih. Od kopna je Bračkim kanalom udaljen 6 do 13 kilometara, od otoka Šolte je odvojen Splitskim vratima, a prema jugu je od Hvara odvojen Hvarskim kanalom. Izgrađen je od karbonatnovapnenačkih stijena, a najviši mu je vrh Vidova gora, inače i najviši vrh jadranskih

19 Odluka o obuhvatu i razvrstavanju jedinica lokalne samouprave koje stječu status brdskoplaninskog područja, NN 24/19.

20 Županijska razvojna strategija Splitsko-dalmatinske županije za razdoblje do 2020. godine, http:// www.rera.hr/upload/stranice/2017/02/2017-02-09/34/nacrtupanijskerazvojnestrategije.pdf (2. IX. 2019.).

21 http://www.poslovni.hr/hrvatska/strategija-imotske-krajine-putokaz-svima-350965 (6. IX. 2019.). Važno je spomenuti da su praktično sve imotske općine donijele i svoje posebne strategije razvoja, u kojima naglašavaju bitne odrednice daljnjeg razvoja naročito apostrofirajući mjere održivog razvoja. U tom smislu može se kao paradigmatičnu spomenuti Strategiju razvoja općine Runovići za razdoblje 2016. - 2021., https:/www.runovici.hr/Strategija-razvoja-opcine-Runovici-fin-s. pdf (7. VII. 2019.). 
otoka $(778 \mathrm{~m} / \mathrm{nm})$. Ime otoka potječe od ilirske riječi brentos za jelena. ${ }^{22}$ Otok Brač nastanjuju 16.524 stanovnika.

Za komunalnu povijest otoka Brača od izuzetne je važnosti Brački statut iz 1305. po kojem su Bračani živjeli sve do propasti Mletačke Republike 1797., dakle gotovo pola tisućljeća. ${ }^{23}$

Glavne gospodarske grane na otoku Braču jesu turizam koji, zahvaljujući prirodnim ljepotama i znamenitostima otoka (plaža Zlatni rat, Vidova gora, Pustinja Blaca, makadamske ceste, biciklističke staze, ranokršćanske bazilike u mjestu Postira i uvali Lovrečina, Dominikanski samostan s muzejom u Bolu, etno-eko selo Dol...) zajednički razvijaju turističko-ugostiteljska poduzeća ("Zlatni rat", "Svpetrvs hoteli" i dr.) i fizičke osobe kao vlasnici apartmana i obrta; ribarstvo čiji je glavni pokretač tvornica "Sardina"; kamenoklesarstvo u kojoj djelatnosti prednjače poduzeće "Jadrankamen" i brojni obrti te maslinarstvo. Gospodarskom razvoju otoka Brača od velike je pomoći izuzetno dobra povezanost otoka s kopnom za što su osigurana adekvatna sredstva iz državnog proračuna radi financiranja brodara, a stalna su i ulaganja iz županijskog i državnog proračuna u infrastrukturu (luke, ceste i dr.). Sve jedinice lokalne samouprave osnovale su vlastite turističke zajednice.

Otežane uvjete života i rada na otoku zakonodavac je prepoznao i nastoji ih otkloniti i Zakonom o otocima kojim se uređuje način upravljanja razvojem hrvatskih otoka, zaštitom otoka i otočića u Jadranskom moru te poluotoka Pelješca, određuje politika otočnog razvoja, tijela nadležna za upravljanje otočnim razvojem, razvrstavanje otoka u skupine i vrednovanje razvijenosti otoka, praćenje i izvještavanje o provedbi politike otočnog razvoja u svrhu učinkovitog korištenja sredstava državnog proračuna, fondova Europske unije i drugih izvora financiranja. S obzirom na interes Republike Hrvatske za osobitu zaštitu otoka, uređuje se način na koji se otočna dobra mogu upotrebljavati i iskorištavati te razvojna politika usmjerena na prevladavanje ograničenja kojima su otoci podvrgnuti, a ustanovljen je i program "Hrvatski otočni proizvod", čiji su cilj poticanje proizvodnje i plasmana te promocija izvornih i inovativnih otočnih proizvoda, tradicije i baštine (čl. 1., 3. i 36. Zakona o otocima).

22 Mayer, Antun, "O starijim mjesnim imenima obale srednje Dalmacije", Hrvatski geografski glasnik, 8-10/1939., str. 145.

23 Cvitanić, Antun, Brački statut, Split: Književni krug, 2006., str. 8. 


\section{USTROJSTVO, VELIČINA, NASTANJENOST I NEKI KADROVSKI ASPEKTI JEDINICA LOKALNE SAMOUPRAVE U IMOTSKOJ KRAJINI I NA OTOKU BRAČU ${ }^{24}$}

\subsection{Jedinice lokalne samouprave, stanovništvo i naselja}

Dugo vremena u bivšoj državi pa sve do velike reforme komunalnog sustava Republike Hrvatske, na području Imotske krajine djeluje jedinstvena Općina Imotski, a za cijeli otok Brač ustrojena je Općina Brač, da bi do fragmentacije jedinica lokalne samouprave došlo krajem 1992. godine donošenjem Zakona o području županija, gradova i općina u Republici Hrvatskoj, kojim se na području Imotske krajine utvrđuju Grad Imotski i općine: Podbablje, Cista Provo, Lovreć, Donji Proložac, Zmijavci-Runović i Zagvozd, a na otoku Braču općine: Bol, Pučišća, Postira, Selca, Supetar, Milna i Nerežišća. Tijekom narednog razdoblja na oba područja povećava se broj jedinica lokalne samouprave (osnivaju se nove općine Sutivan i Lokvičići, a postojeća općina Zmijavci-Runovići dijeli se na nove općine Zmijavci i Runovići), općina Supetar dobiva status grada, pa je sadašnje stanje, utvrđeno važećim Zakonom o područjima županija, gradova i općina u Republici Hrvatskoj, ${ }^{25}$ sljedeće:

- na području Imotske krajine ustrojeni su Grad Imotski (sa 6 naselja: Imotski, Vinjani Donji, Vinjani Gornji, Donja Glavina, Gornja Glavina, Medvidovića Draga) i osam općina: Cista Provo (sa 6 naselja: Cista Provo, Aržano, Biorine, Cista Velika, Dobranje, Svib), Lokvičići (sa 2 naselja: Lokvičići, Dolića Draga), Lovreć (sa 5 naselja: Lovreć, Dobrinče, Medov Dolac, Opanci, Studenci), Podbablje (sa 8 naselja: Drum, Grubine, Hršćevani, Ivanbegovina, Kamenmost, Krivodol, Podbablje Gornje, Poljica), Proložac (sa 5 naselja: Donji Proložac, Gornji Proložac, Postranje, Ričice, Šumet), Runovići (sa 3 naselja: Runović, Podosoje, Slivno), Zagvozd (sa 7 naselja: Zagvozd, Biokovsko Selo, Krstatice, Rastovac, Raščćane Gornje, Župa, Župa Srednja), Zmijavci (sa 1 naseljem: Zmijavci).

- na području otoka Brača postoje Grad Supetar (sa 4 naselja: Supetar, Mirca, Škrip, Splitska) 7 općina: Bol (sa 2 naselja: Bol, Murvica), Milna (sa 5 naselja:

24 Statističke podatke o mjesnim odborima, upravnom osoblju, obavljanju dužnosti gradonačelnika/ načelnika i njihovih zamjenika, proračuna i određenim aspektima njegova punjenja odnosno trošenja, autori su prikupili od jedinica lokalne samouprave u Imotskoj krajini i na otoku Braču na temelju anketnog upitnika koji im je dostavljen u travnju 2019., a isti podaci su radi usporedbe pribavljeni i od jedinica lokalne samouprave na otocima Hvaru i Visu te od općine Otok i od grada Trilja u Sinjskoj krajini. U zakonskom roku od 15 dana (čl. 20. st. 1. Zakona o pravu na pristup informacijama, NN 25/13, 85/15) podatke za bračke jedinice lokalne samouprave dostavile su općine Nerežišća i Postira, u Imotskoj krajini tu obvezu u okviru zakonskog roka nije ispunila nijedna jedinica lokalne samouprave, već je to učinjeno sa znatnim zakašnjenjem, a posebice se to odnosi na najveću općinu po broju stanovnika: Podbablje. Na traženje proračunskih podataka neposredno od lokalnih jedinica, autori su potaknuti negativnom ocjenom transparentnosti općina u Splitsko-dalmatinskoj županiji (Ott, Katarina et al, Newsletter, 117/2019, str. 5).

25 Zakon o područjima županija, gradova i općina u Republici Hrvatskoj, NN 86/06, 125/06, 16/07, 95/08, 46/10, 145/10, 37/13, 44/13, 45/13, 110/15. 
Milna, Ložišća, Bobovišća, Bobovišća na Moru, Podhume), Nerežišća (sa 3 naselja: Nerežišća, Dračevica, Donji Humac), Postira (sa 2 naselja: Postira, Dol), Pučišća (sa 3 naselja: Pučišća, Gornji Humac, Pražnica), Selca (sa 4 naselja: Selca, Povlja, Sumartin, Novo Selo), Sutivan (sa 1 naseljem: Sutivan).

Grad Imotski ima 11.584 stanovnika i ispunjava zakonski uvjet za dobivanje statusa grada, dok je takav status Supetru dodijeljen temeljem izuzetno dozvoljene mogućnosti da se gradom utvrdi i naselje s manje od 10.000 stanovnika (čl. 5. Zakona o lokalnoj i područnoj (regionalnoj) samoupravi). ${ }^{26}$ Jedna općina (Podbablje) ima više od 5000 stanovnika, a dvije općine imaju manje od 1000 stanovnika (Nerežišća, Lokvičići), dvije općine imaju samo jedno naselje (Zmijavci, Sutivan) iako je čl. 4. ZLP(R)S-a propisao da se općine, u pravilu, osnivaju za područje više naselja.

Sve jedinice imaju službene web-stranice.

\subsection{Mjesni odbori}

Iako je zakonom propisano da se mjesni odbori osnivaju statutom jedinica lokalne samouprave kao oblik neposrednog sudjelovanja građana u odlučivanju o lokalnim poslovima od neposrednog i svakodnevnog utjecaja na život građana, a zakonodavac im je dodijelio i status pravne osobe ${ }^{27}$ (čl. 57. st. 1. i čl. 66. ZLP(R) S)-a, grad Supetar je formirao mjesne odbore u svim naseljima, dok grad Imotski to nije učinio niti u jednom naselju, a dio općina nije uopće formirao mjesne odbore (u Imotskoj krajini: Lokvičići, Zagvozd, Zmijavci, na otoku Braču: Bol, Milna, Nerežišća, Pučišća, Selca, Sutivan) ili je to učinjeno za manji broj naselja. ${ }^{28}$

\subsection{Službenici i namještenici}

U Imotskoj krajini najveći broj službenika i namještenika ima grad Imotski, a najmanji općine Proložac i Runovići, dok je na otoku Braču najveći broj službenika i namještenika zaposlen u gradu Supetru, a najmanji u općinama Milna i Nerežišća. U odnosu na broj stanovnika u Imotskoj krajini, najveći broj zaposlenih službenika i namještenika ima općina Zagvozd (1:420), a najmanji općina Proložac (1:4151), dok na otoku Braču najveći broj zaposlenih službenika i namještenika ima općina Sutivan (1:160), a najmanji općina Pučišća (1:324).

Sve jedinice imaju Jedinstveni upravni odjel.

26 Zakon o lokalnoj i područnoj (regionalnoj) samoupravi (ZLP(R)S), NN 33/01, 60/01, 129/05, 109/07, 125/08, 36/09, 150/11, 144/12, 19/13, 137/15, 123/17.

27 O značaju (ulozi) mjesnih odbora, detaljnije vidi u: Tropina Godec, Željka, "Oblici mjesne samouprave", Pravo i porezi, broj 3/2018., str. 36-43.

${ }_{28}$ U većini jedinica lokalne samouprave na otoku Hvaru (gradovi: Hvar i Stari Grad, općina Jelsa) u većini naselja osnovani su mjesni odbori, dok niti jedan mjesni odbor nije osnovan u općini Sućuraj na istočnom dijelu tog otoka. Jedinice lokalne samouprave na otoku Visu (gradovi: Komiža i Vis) nisu osnovale niti jedan mjesni odbor. Općina Otok i grad Trilj mjesne su odbore osnovali u većini svojih naselja. 


\subsection{Profesionalno obavljanje dužnosti gradonačelnika/načelnika i zamjenika gradonačelnika/načelnika}

Zakonodavac je propisao da čelnik jedinice lokalne samouprave koja ima do 10.000 stanovnika ima jednog zamjenika, a u jedinicama iznad 10.000 stanovnika 2 zamjenika (čl. 41. ZLP(R)S)-a. U gradu Imotskome i gradonačelnik i zamjenici gradonačelnika dužnost obavljaju volonterski, a u općini Podbablje načelnik svoju dužnost obavlja volonterski. U gradu Supetru zamjenik gradonačelnika te u općinama Milna, Postira, Proložac, Lokvičići, Lovreć, Zagvozd i Zmijavci zamjenici načelnika svoju dužnost obavljaju volonterski i bez naknade, a u općinama Bol, Pučišća i Runovići dužnost obavljaju volonterski uz novčanu naknadu. ${ }^{29}$

Tablica 1. Broj stanovnika, naselja, mjesnih odbora, službenika/namještenika u jedinicama lokalne samouprave Imotske krajine

\begin{tabular}{|c|c|c|c|c|c|c|c|}
\hline $\begin{array}{l}\text { Jedinice } \\
\text { lokalne } \\
\text { samouprave }\end{array}$ & 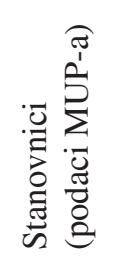 & 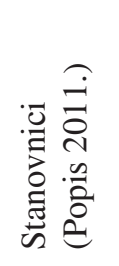 & 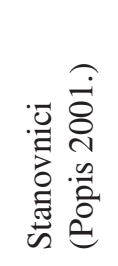 & 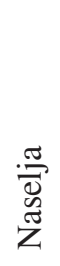 & 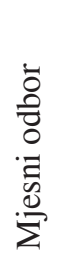 & 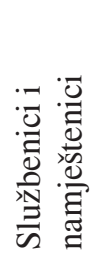 & 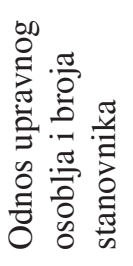 \\
\hline Imotski & 11.584 & 10.764 & 10.213 & 6 & 0 & 15 & $1: 772$ \\
\hline Cista Provo & 2651 & 2335 & 3674 & 6 & 6 & 2 & $1: 1326$ \\
\hline Lokvičići & 972 & 807 & 1037 & 2 & 0 & 2 & $1: 486$ \\
\hline Lovreć & 1867 & 1669 & 2500 & 5 & 5 & 1 & $1: 186$ \\
\hline Podbablje & 5080 & 4680 & 4904 & 8 & 8 & 6 & $1: 847$ \\
\hline Proložac & 4151 & 3802 & 4510 & 5 & 3 & 1 & $1: 4151$ \\
\hline Runovići & 2537 & 2416 & 2643 & 3 & 3 & 1 & $1: 2537$ \\
\hline Zagvozd & 1260 & 1188 & 1642 & 7 & 0 & 3 & $1: 420$ \\
\hline Zmijavci & 2141 & 2048 & 2130 & 1 & 0 & 2 & 1:535 \\
\hline
\end{tabular}

29 U jedinicama lokalne samouprave na otocima Hvaru i Visu profesionalno obavljaju svoju dužnost svi gradonačelnici i načelnici te većina njihovih zamjenika, uz iznimku zamjenika gradonačelnika u Starom Gradu i zamjenika načelnika u općini Sućuraj, koji su volonteri. U općini Otok načelnik i njegov zamjenik dužnost obavljaju profesionalno, dok su i gradonačelnik i njegov zamjenik u Trilju volonteri. 
Tablica 2. Broj stanovnika, naselja, mjesnih odbora, službenika/namještenika u jedinicama lokalne samouprave otoka Brača

\begin{tabular}{|c|c|c|c|c|c|c|c|}
\hline $\begin{array}{l}\text { Jedinice } \\
\text { lokalne } \\
\text { samouprave }\end{array}$ & 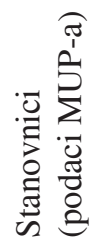 & 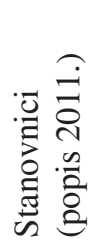 & 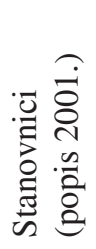 & 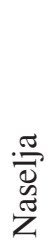 & $\begin{array}{l}\overline{0} \\
0 \\
0 \\
0 \\
\overline{0} \\
\stackrel{0}{\Sigma}\end{array}$ & 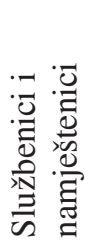 & 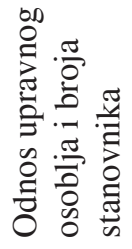 \\
\hline Supetar & 5026 & 4074 & 3889 & 4 & 4 & 19 & $1: 265$ \\
\hline Bol & 1969 & 1630 & 1661 & 2 & 0 & 11 & $1: 179$ \\
\hline Milna & 1296 & 1034 & 1100 & 5 & 0 & 6 & $1: 216$ \\
\hline Nerežišća & 992 & 862 & 868 & 3 & 0 & 6 & $1: 165$ \\
\hline Postira & 1806 & 1559 & 1553 & 2 & 1 & 8 & $1: 226$ \\
\hline Pučišća & 2271 & 2171 & 2224 & 3 & 0 & 7 & $1: 324$ \\
\hline Selca & 2043 & 1804 & 1997 & 4 & 0 & 10 & $1: 204$ \\
\hline Sutivan & 1121 & 822 & 759 & 1 & 0 & 7 & $1: 160$ \\
\hline
\end{tabular}

\section{NEKI ASPEKTI PRIHODA I RASHODA PRORAČUNA JEDINICA LOKALNE SAMOUPRAVE U IMOTSKOJ KRAJINI I NA OTOKU BRAČU}

\subsection{Proračun za 2018. i 2019. godinu}

U 2018. godini u Imotskoj krajini najveći proračun imao je grad Imotski, a najmanji proračun ostvarila je općina Zagvozd, dok je na otoku Braču najveći proračun imao grad Supetar, a najmanji proračun ostvarila je općina Nerežišća.

Gradovi Imotski i Supetar, te većina općina, uz izuzetak općina Proložac, Postira i Selca, planirali su veći proračun za 2019. godinu.

Prihod proračuna iz europskih fondova za 2018. godinu 
Samo grad Supetar, te četiri općine u Imotskoj krajini (Lokvičići, Lovreć, Runovići i Zagvozd) i dvije općine na otoku Braču (Nerežišća, Selca) ostvarili su prihod proračuna iz fondova Europske unije. ${ }^{30}$

Naknade za rad (sjednice) vijećnicima u 2018. godini

Naknade za rad (sjednice) općinskim vijećnicima nisu za 2018. odredili odnosno isplatili grad Imotski, ni općine Postira, Selca, Sutivan, Lokvičići i Proložac, dok su to učinili grad Supetar i ostale općine. ${ }^{31}$ Ukupno najviše sredstava za naknade u Imotskoj krajini isplatila je općina Lovreć: 67.151 kn, a na otoku Braču Općina Milna: $75.498 \mathrm{kn} .^{32}$

Naknade za vanjske članove gradskih/općinskih odbora u 2018. godini

Naknade vanjskim članovima gradskih/općinskih odbora isplatile su samo bračke općine Bol i Pučišća.

Rashodi za zaposlene u gradskoj/općinskoj upravi za 2018. godinu

Rashodi za zaposlene u gradskoj/općinskoj upravi kretali su se u rasponu od 2,00\% (općina Cista Provo) do 9,70\% proračuna (općina Nerežišća).

Stipendije đacima/studentima i davanja po osnovi socijalne skrbi za 2018. godinu

Svi gradovi i općine u Imotskoj krajini i na otoku Braču isplaćivali su stipendije đacima i studentima te davanja po osnovi socijalne skrbi.

Tablica 3. Iznos proračuna, prihodi iz EU-fondova, naknade vijećnicima i rashodi za službenike i namještenike u jedinicama lokalne samouprave u Imotskoj krajini

\begin{tabular}{|l|r|r|r|r|r|}
\hline $\begin{array}{c}\text { Jedinice } \\
\text { lokalne } \\
\text { samouprave }\end{array}$ & $\begin{array}{c}\text { Proračun za } \\
\text { 2018. (kn) }\end{array}$ & $\begin{array}{c}\text { Planirani } \\
\text { proračun za } \\
\text { 2019. (kn) }\end{array}$ & $\begin{array}{c}\text { Prihod iz } \\
\text { EU-fondova u } \\
\text { 2018. (kn) }\end{array}$ & $\begin{array}{c}\text { Naknade } \\
\text { vijećnicima u } \\
\text { 2018. (kn) }\end{array}$ & $\begin{array}{c}\text { Rashodi za } \\
\text { službenike i } \\
\text { namještenike } \\
\text { u 2018. (u \%) }\end{array}$ \\
\hline Imotski & $42.386 .102,65$ & $49.148 .000,00$ & 0 & 0 & $6,00 \%$ \\
\hline Cista Provo & $8.225 .328,00$ & $14.909 .000,00$ & 0 & $49.441,00$ & $2,00 \%$ \\
\hline Lokvičići & $5.938 .048,00$ & $7.281 .003,00$ & $401.741,60$ & 0 & $7,13 \%$ \\
\hline
\end{tabular}

30 U 2018. godini na otoku Hvaru prihod iz europskih fondova ostvario je grad Hvar (2.240.619 kn), na otoku Visu to je uspio grad Komiža (3.824.012 kn), općina Otok nije imala navedeni prihod, dok je grad Trilj uprihodio sredstva iz europskih fondova $(137.681,70 \mathrm{kn})$. Što se imotskih općina i grada Imotskoga tiče, činjenica je da u odgovorima o prikupljanju sredstava iz fondova EU-a nismo dobili egzaktne pokazatelje, no sigurno je da su povukli ta sredstva za realizaciju javnih komunalnih radova, kao i za program poticanja zapošljavanja žena iznad 50 godina starosti kao njegovateljica starijih osoba. Pouzdano znamo da je općina Zagvozd zajedno s gradom Imotskim povukla sredstva u iznosu koji je naveden u tablici 3 za realizaciju vodovodne mreže i asfaltiranje općinskih cesta, a to su učinile i druge općine, no nisu sve dostavile točne pokazatelje.

31 Općina Nerežišća naknadu je vijećnicama (podzastupljeni spol) uvećala za $10 \%$.

32 Naknade vijećnicima za sjednice vijeća isplatile su sve jedinice lokalne samouprave na otocima Hvaru i Visu, osim općine Sućuraj, kao i općina Otok i grad Trilj, a za ovu namjenu daleko najviše sredstava isplatio je grad Hvar (130.075 kn). 
Prof. dr. sc. Duško Lozina i dr. sc. Damir Juras: Neke karakteristike lokalne samouprave na prostoru... Zbornik radova Pravnog fakulteta u Splitu, god. 56, 4/2019, str. 817-834

\begin{tabular}{|l|r|r|r|r|r|}
\hline $\begin{array}{c}\text { Jedinice } \\
\text { lokalne } \\
\text { samouprave }\end{array}$ & $\begin{array}{c}\text { Proračun za } \\
\text { 2018. (kn) }\end{array}$ & $\begin{array}{c}\text { Planirani } \\
\text { proračun za } \\
\text { 2019. }(\mathrm{kn})\end{array}$ & $\begin{array}{c}\text { Prihod iz } \\
\text { EU-fondova u } \\
\text { 2018. }(\mathrm{kn})\end{array}$ & $\begin{array}{c}\text { Naknade } \\
\text { vijećnicima u } \\
\text { 2018. (kn) }\end{array}$ & $\begin{array}{c}\text { Rashodi za } \\
\text { službenike i } \\
\text { namještenike } \\
\text { u 2018. (u \%) }\end{array}$ \\
\hline Lovreć & $5.365 .087,00$ & $8.619 .523,00$ & $72.612,00$ & $67.151,00$ & $7,85 \%$ \\
\hline Podbablje & $11.862 .659,00$ & $28.671 .700,00$ & 0 & $36.827,92$ & $5,69 \%$ \\
\hline Proložac & $9.164 .000,00$ & $8.340 .000,00$ & 0 & 0 & $3,10 \%$ \\
\hline Runovići & $7.217 .200,00$ & $7.950 .000,00$ & $1.241 .634,00$ & $30.250,00$ & $4,03 \%$ \\
\hline Zagvozd & $4.750 .997,00$ & $23.364 .500,00$ & 4.3222 .000 & $10.200,00$ & $8,88 \%$ \\
\hline Zmijavci & $8.658 .000,00$ & $8.989 .800,00$ & 0 & 8800,00 & $3,00 \%$ \\
\hline
\end{tabular}

Tablica 4. Iznos proračuna, prihodi iz EU-fondova, naknade vijećnicima i rashodi za službenike i namještenike u jedinicama lokalne samouprave na otoku Braču

\begin{tabular}{|c|c|c|c|c|c|}
\hline $\begin{array}{c}\text { Jedinice } \\
\text { lokalne } \\
\text { samouprave }\end{array}$ & $\begin{array}{l}\text { Proračun } \\
\text { za } 2018 .\end{array}$ & $\begin{array}{l}\text { Planirani } \\
\text { proračun } \\
\text { za } 2019 .\end{array}$ & $\begin{array}{l}\text { Prihod iz EU- } \\
\text { fondova } \\
\text { u } 2018\end{array}$ & $\begin{array}{l}\text { Naknade } \\
\text { vijećnicima } \\
\text { u } 2018 .\end{array}$ & $\begin{array}{c}\text { Rashodi za } \\
\text { službenike i } \\
\text { namještenike } \\
\text { u 2018. (u \%) }\end{array}$ \\
\hline Supetar & $31.159 .378,00$ & $57.119 .277,38$ & $474.502,18$ & $46.440,54$ & $7,75 \%$ \\
\hline Bol & $23.468 .000,00$ & $32.662 .020,00$ & 0 & $72.231,00$ & $7,50 \%$ \\
\hline Milna & $7.523 .957,00$ & $10.536 .000,00$ & 0 & $75.498,00$ & $8,80 \%$ \\
\hline Nerežišća & $6.766 .581,00$ & $13.030 .880,00$ & $300.000,00$ & 4600,00 & $9,70 \%$ \\
\hline Postira & $10.492 .231,00$ & $10.463 .000,00$ & 0 & 0 & $7,10 \%$ \\
\hline Pučišća & $8.198 .327,00$ & $26.499 .262,00$ & 0 & $42.635,79$ & $6,05 \%$ \\
\hline Selca & $11.723 .000,00$ & $11.210 .000,00$ & $1.628 .525,60$ & 0 & $6,00 \%$ \\
\hline Sutivan & $16.810 .578,33$ & $31.207 .500,00$ & 0 & 0 & $7,12 \%$ \\
\hline
\end{tabular}

\section{ZAKLJUČAK}

Grad Imotski status grada dobio je na temelju osnovnog kriterija broja stanovnika, dok je Supetar dobio status grada temeljem kriterija izuzetnosti. Uz izuzetak općine Podbablje (5080 stanovnika), ostale općine spadaju u kategoriju malih općina (do 
5000 stanovnika), a velik dio općina ima do 2500 stanovnika ili čak manje od 1000 stanovnika (Nerežišća, Lokvičići) pa ih se može nazvati vrlo malima. ${ }^{33}$

U Imotskoj krajini općina Zmijavci, a na otoku Braču općina Sutivan imaju samo jedno naselje, čime se poništava jedna od temeljnih intencija politipske organizacije, koja i postoji zato da bi se izrazili i rješavali specifični problemi u jedinicama koje su različite po objektivnim okolnostima i po političkim interesima ljudi. ${ }^{34}$

Submunicipalne jedinice igraju različite (važne) uloge u lokalnim političkim sustavima, kao animator lokalnih aktivnosti, reprezentanta lokalnih interesa, odgajaju političare za više političke položaje. ${ }^{35}$ Očito je da lokalna vlast, ali ni građani koji uz članove predstavničkih tijela i drugih tijela određenih statutom općine odnosno grada mogu dati inicijativu i prijedlog za osnivanje mjesnog odbora (čl. 58. ZLPRS-a), nisu prepoznali važnost i ulogu mjesnih odbora, pa u 4 lokalne jedinice na području Imotske krajine i 6 lokalnih jedinica na otoku Braču nije osnovan niti jedan mjesni odbor, a mjesne odbore u svim naseljima osnovali su samo grad Supetar i općine Lovreć, Runovići, Podbablje i Cista Provo. Na nezainteresiranost za osnivanje mjesnih odbora može utjecati nedovoljni financijski kapacitet tih tijela, ali se on neće povećati pasivnim pristupom građana. ${ }^{36}$

Prema objavljenom istraživanju o zaposlenima u jedinicama lokalne samouprave, u upravnim je tijelima općina 2008. bilo zaposleno 3376 službenika i namještenika (u prosjeku 7,86 po općini). ${ }^{37}$ Uspoređujući broj upravnog osoblja u jedinicama lokalne samouprave Imotske krajine i otoka Brača s navedenim prosjekom u Republici Hrvatskoj, vidljivo je da je broj službenika i namještenika u Imotskoj krajini ispod prosjeka, dok se u bračkim jedinicama kreće u razini ili iznad prosjeka. Za primijetiti je i da broj službenika i namještenika u navedenim gradovima i općinama nije razmjeran broju stanovnika, pri čemu je vidljivo da je u odnosu na broj stanovnika znatno više službenika i namještenika zaposleno u bračkim lokalnim jedinicama.

Zamjenici gradonačelnika u Imotskom i Supetru te 10 zamjenika općinskih načelnika svoju dužnost obavljaju volonterski (od kojih trojica primaju naknadu), a 5 zamjenika načelnika dužnost obavlja profesionalno, pri čemu je posebno

33 Prema podacima iz Popisa stanovništva 2011. godine, u Republici Hrvatskoj je do 1000 stanovnika imalo 37 općina (8,62 \%), između 1001 i 2500 stanovnika imale su 183 općine (42,66 \%), a između 2501 i 5000 stanovnika imalo je 156 općina $(36,37 \%)$. str. 376

34 Koprić, "Karakteristike sustava lokalne samouprave u Hrvatskoj", Hrvatska javna uprava, 2/2010,

35 Više o submunicipalnom upravljanju u Europi vidi u uvodu knjige (str. 1-24) autora: Hlepas, Nikolaos-Kamninos; Kuhlmann, Sabine; Teles, Filipe; Kersting, Norbert; Swianiewicz, Pavel, SubMunicipal Governance in Europe: Decentralization Beyond the Municipal Tier, Palgrave Macmillan, 2018.

36 Manojlović Toman, Romea; Vukojičić Tomić, Tijana; Koprić, Ivan, "Neuspješna europeizacija hrvatske mjesne samouprave: Nedovoljna atraktivnost ili loše institucionalno oblikovanje", Godišnjak Akademije pravnih znanosti Hrvatske, 1/2019, str. 185-210. Provedena je analiza proračuna u određenim hrvatskim gradovima i utvrđeno je da je udio proračuna koji je namijenjen radu mjesnih odbora (posebna stavka u gradskom proračunu) manji od $1 \%$.

37 Bajo, A., Institut za javne financije, srpanj 2009., prema: Ivanović, Mladen, "Problemi malih općina u svjetlu nove regulacije lokalne samouprave", u: Koprić, Ivan; Đulabić, Vedran (ur.), Dvadeset godina lokalne samouprave u Hrvatskoj, Zagreb: Institut za javnu upravu, 2013., str. 206. 
interesantno da su obje čelne dužnosti profesionalizirane na otoku Braču u općini s najmanjim brojem stanovnika (Nerežišća) i u općini koja ima samo jedno naselje (Sutivan). Zamjenici općinskih načelnika, posebice u kategoriji malih općina, a sasvim sigurno u onim vrlo malim, postaju značajan financijski teret, a iz prikazanih je podataka vidljivo da je moguće organizirati funkcioniranje lokalne samouprave i bez profesionaliziranja navedene funkcije, pa je u tom smislu opravdano očekivati i zakonsku novelu kako bi se to i normativno spriječilo.

Velika većina jedinica lokalne samouprave nije uspjela ostvariti prihod iz europskih fondova, a iznos koji je ostvaren od strane grada Supetra, te općina Lokvičići, Lovreć, Runovići, Zagvozd, Nerežišća i Selca, pokazuje da je privlačenje tih sredstava ovisno o sposobnosti osoblja i pripremljenosti projekata, a ne o veličini lokalne jedinice, njezinom broju stanovnika ili broju njezinog upravnog osoblja.

Prof. Koprić načelno ističe da općine ne bi trebale biti manje od 5000 stanovnika, osim iznimno, jer se upravo taj broj smatra nužnim za mogućnost obavljanja tipičnih javih službi, ${ }^{38}$ međutim nije samo broj stanovnika bitan za formiranje odnosno uspješno funkcioniranje općina, već je to njezin fiskalni kapacitet, ali i odgovarajuće određivanje nadležnosti i pravnih pretpostavki za postizanje ciljeva. Dakle, samo teritorijalno prekrajanje Hrvatske, pa tako i u odnosu na područje Imotske krajine i otoka Brača, ne daje jamstva da će neka nova teritorijalna struktura, u kojoj će lokalne jedinice biti veće nego danas, omogućiti kvalitetno ostvarivanje temeljnih funkcija lokalne samouprave odnosno da će građanima biti pružene kvalitetnije usluge ${ }^{39} \mathrm{U}$ tom smislu Ivanović nudi dva rješenja, koja su prihvatljiva odnosno provediva i za jedinice lokalne samouprave u Imotskoj krajini i na otoku Braču: da se sustav prilagodi na način da počne uvažavati različitosti lokalnih jedinica (tako da npr. samoupravni djelokrug lokalnih jedinica bude različit s obzirom na njihovu veličinu i druge kapacitete, da se na različit način ustroje izvršna tijela za velike i male, reformira način financiranja lokalne samouprave i sl.) odnosno da se intenzivnije koristi međuopćinska suradnja kako bi se poslovanje malih općina racionaliziralo, a postojeći kapaciteti iskoristili na najbolji mogući način, ${ }^{40}$ što je zakonodavac već omogućio odredbom da dvije ili više jedinica lokalne samouprave mogu obavljanje poslova iz svoga samoupravnog djelokruga organizirati zajednički i radi toga osnovati zajedničko tijelo, zajednički upravni odjel ili službu, zajedničko trgovačko društvo ili mogu zajednički organizirati njihovo obavljanje u skladu s posebnim zakonom (čl. 54. ZLP(R)S-a).

38 Koprić, Ivan, Dvadeset godina lokalne i područne (regionalne) samouprave u Hrvatskoj: razvoj, stanje i perspektive, str. 26.

39 Prof. Kregar i suradnici ističu da sam postupak ukidanja ili spajanja malih jedinica nije jamstvo promjene već da se koordinirane i koherentne reforme moraju istodobno provesti i u modelu izbora, odnosima glavnih tijela lokalne vlasti, povećanju odgovornosti za javne službe i dr., Kregar, Josip, et. al., Decentralizacija, Zagreb: Centar za demokraciju i pravo Miko Tripalo, 2011., str. 20.

40 Ivanović, Mladen, "Problemi malih općina u svjetlu nove regulacije lokalne samouprave", u: Koprić, Ivan; Đulabić, Vedran (ur.), Dvadeset godina lokalne samouprave u Hrvatskoj, Zagreb: Institut za javnu upravu, 2013., str. 222. 


\section{LITERATURA}

1. Bajo, Anto, Institut za javne financije, srpanj 2009., prema: Ivanović, Mladen, "Problemi malih općina u svjetlu nove regulacije lokalne samouprave", u: Koprić, Ivan; Đulabić, Vedran (ur.), Dvadeset godina lokalne samouprave u Hrvatskoj, Zagreb: Institut za javnu upravu, 2013.

2. Cvitan, Onesin: Lokalna samouprava, Split: Veleučilište u Splitu, 2003.

3. Cvitanić, Antun, Brački statut, Split: Književni krug,, 2006.

4. https://data.gov.hr/dataset/popis-stanovni-tva-2011-po-gradovima-op-inama/ resource/9644ed4e-a734-406d-b088-5c44ce9d077f

5. https://uprava.gov.hr/o-ministarstvu/ustrojstvo/uprava-za-politicki-sustav-iorganizaciju-uprave/lokalna-i-podrucna-regionalna-samouprava/popis-zupanijagradova-i-opcina/846

6. https://www.dzs.hr/Hrv/censuses/Census2001/Popis/H01_01_02/h01_01_02_zup17. html https://www.dzs.hr/Hrv/censuses/census2011/results/censusmetod.htm

7. http://www.rera.hr/upload/stranice/2017/02/2017-02-09/34/ nacrtupanijskerazvojnestrategije.pdf

8. https:/www.runovici.hr/Strategija-razvoja-opcine-Runovici-fin-s. pdf

9. Grbavac, Jozo, Povijest, vjera i kulturna baština u Imoti, Zagreb: Školska knjiga, 2017.

10. Humes, Samuel; Martin, Eileen, The Structure of Local Government, A Comparative Survey of 81 Countries, The Hague: International Union of Local Authorities, 1969.

11. Hlepas, Nikolaos-Kamninos; Kuhlmann, Sabine; Teles, Filipe; Kersting, Norbert; Swianiewicz, Pavel, Sub-Municipal Governance in Europe: Decentralization Beyond the Municipal Tier, Palgrave Macmillan, 2018.

12. Ivanović, Mladen, "Problemi malih općina u svjetlu nove regulacije lokalne samouprave", u: Koprić, Ivan; Đulabić, Vedran (ur.), Dvadeset godina lokalne samouprave u Hrvatskoj, Zagreb: Institut za javnu upravu, 2013.

13. Klarić, Mirko, "Moguće perspektive razvoja lokalne i regionalne samouprave u Republici Hrvatskoj", Zbornik radova Teritorijalni ustroj i regionalizacija Republike Hrvatske u kontekstu europskih integracija, Split: Pravni fakultet Sveučilišta u Splitu, 2010.

14. Klarić, Mirko, "Zakonske novine vezane iz izvršne institucije u lokalnoj samoupravi", u: Koprić, Ivan; Đulabić, Vedran (ur.), Dvadeset godina lokalne samouprave $u$ Hrvatskoj, Zagreb: Institut za javnu upravu, 2013.

15. Koprić, Ivan, Dvadeset godina lokalne $i$ područne (regionalne) samouprave u Hrvatskoj: razvoj, stanje i perspektive,

16. https://s3.amazonaws.com/academia.edu.documents/36414896/KopricDvadeset_godina_LRSMP_-_predavanja_2012_1_.pdf?response-contentdisposition=inline \%3B\%20filename\%3DDvadeset_godina_lokalne_i_podrucne_ regio.pdf\&X-Amz-Algorithm=AWS4-HMAC-SHA256\&X-Amz-Credential $=$ AKIAIWOWYYGZ2Y53UL3A\%2F20190910\%2Fus-east-1\%2Fs3\%2Faws4_ request $\& X-A m z-D a t e=20190910$ T083512Z\&X-Amz-Expires=3600\&X-Amz- 
SignedHeaders $=$ host $\& X-A m z-$ Signature $=0 \mathrm{e} 7 \mathrm{f} 2 \mathrm{e} 31 \mathrm{~d} 3 \mathrm{cc} 34 \mathrm{~b} 9 \mathrm{ff} 150 \mathrm{ef} 0 \mathrm{~b} 8 \mathrm{~cd} 00 \mathrm{~b} 409 \mathrm{f} 3$ fe8ffe7e5a4b941bea06b4016db9

17. Koprić, Ivan, "Karakteristike sustava lokalne samouprave u Hrvatskoj", Hrvatska javna uprava, 2/2010

18. Kregar, Josip, et. al., Decentralizacija, Zagreb: Centar za demokraciju i pravo Miko Tripalo, 2011.

19. Manojlović Toman, Romea; Vukojičić Tomić, Tijana; Koprić, Ivan, "Neuspješna europeizacija hrvatske mjesne samouprave: Nedovoljna atraktivnost ili loše institucionalno oblikovanje", Godišnjak Akademije pravnih znanosti Hrvatske, 1/2019

20. Maras, Mate; Jukić, Branimir: "Zabiokovlje - značajnija prirodno geografska obilježja", Zbornik radova: Zavičajna baština - HNOS $i$ kurikulum, Split: Književni krug, 2007.

21. Mayer, Antun, "O starijim mjesnim imenima obale srednje Dalmacije", Hrvatski geografski glasnik, broj 8-10/1939.

22. Nakićen, Jelena; Čuka, Ante, "Demografski razvoj otoka Brača i sklonost otočana iseljavanju", Migracijske i etničke teme, broj 3/2016.

23. Odluka o obuhvatu i razvrstavanju jedinica lokalne samouprave koje stječu status brdsko-planinskog područja, NN 24/19.

24. Ora, Branko, "Ruralni turizam - prigoda za revitalizaciju napuštenih sela u Zabiokovlju", Zbornik radova: Zavičajna baština - komparativna prednost $i$ temeljnica održivog razvoja Zabiokovlja, Split: Književni krug, 2009.

25. Ott, Katarina et al., Newsletter, 117/2019.

26. Pavić, Željko, "Veličina lokalnih jedinica - europske tendencije i hrvatske nedoumice", Hrvatska javna uprava, 1/2010.

27. Pusić, Eugen, Teritorijalna konfiguracija lokalnog samoupravljanja u okviru ustavne koncepcije općine, Zagreb: Institut za društvena istraživanja Sveučilišta u Zagrebu, 1968.

28. Pusić, Eugen, Upravni sistemi, knjiga 1, Zagreb: Grafički zavod Hrvatske, Pravni fakultet u Zagrebu, Centar za stručno usavršavanje i suradnju s udruženim radom, 1985.

29. Policijska uprava splitsko-dalmatinska, mail od 27. V. 2019.

30. Statistički podaci dostavljeni od jedinica lokalne samouprave Imotske krajine, otoka: Brača, Hvara i Visa, grada Trilja i općine Otok od travnja do srpnja 2019.

31. Tropina Godec, Željka, "Oblici mjesne samouprave", Pravo i porezi, broj 3/2018.

32. Ujević, Ante, Imotska krajina, Imotski: Matica Hrvatska, 1991.

33. Zakon o brdsko-planinskim područjima, NN 118/18.

34. Zakon o lokalnoj i područnoj (regionalnoj) samoupravi, NN 33/01, 60/01, 129/05, 109/07, 125/08, 36/09, 150/11, 144/12, 19/13, 137/15, 123/17.

35. Zakon o lokalnoj samoupravi i upravi, NN 90/92, 94/93, 117/93, 5/97, 17/99, 128/99, 51/00, 105/00.

36. Zakon o otocima, NN 116/18.

37. Zakon o područjima županija, gradova i općina u Republici Hrvatskoj, NN 90/1992. 
38. Zakon o područjima županija, gradova i općina u Republici Hrvatskoj, NN 86/06, 125/06, 16/07, 95/08, 46/10, 145/10, 37/13, 44/13, 45/13, 110/15.

39. Zakon o pravu na pristup informacijama, NN 25/13, 85/15.

40. Zakon o prebivalištu, NN 144/12, 158/13.

41. Zakon o regionalnom razvoju Republike Hrvatske, NN 147/14, 23/2017, 118/18.

\section{SOME CHARACTERISTICS OF LOCAL SELF-GOVERNMENT IN THE AREA OF IMOTSKA KRAJINA AND ISLAND OF BRAČ}

In this work the authors show the situation of local self-government on the example of two local self-government groups of units, different by their geographic, ecologic, spatial and other characteristics. The subject is about the area of Imotska Krajina which has been differentiated from formerly unique territory area onto 8 communities and the City of Imotski, then the island of Brač which has been divided in 7 municipalities and the City of Supetar. Precisely, such a diversity in the setting of Split-Dalmatia County is the fundamental spiritus movens of this work, unpretentious to give apodictic and decisive judgments of this analysis, for instance on a subject whether the new territory organization has led to an improvement and strengthening of comprehensive capacities of local self-government.

Key words: Imotska Krajina, local self-government, local units' size, Split - Dalmatia County, the island of Brač 